\title{
A pasteurização do império francês
}

\section{The pasteurization of the French Empire}

\author{
Matheus Alves Duarte da Silva \\ ' Doutorando, Centre Alexandre Koyré/École des Hautes Études en Science Sociales. \\ Paris - França \\ orcid.org/0000-0003-0982-6231 \\ matheus.duarte@ehess.fr
}

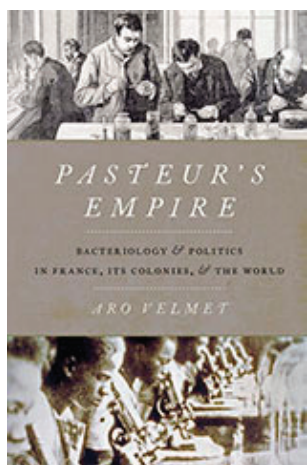

VELMET, Aro. Pasteur's empire: bacteriology and politics in France, its colonies and the world. Oxford: Oxford University Press, 2020. 306p.

Fruto de tese de doutorado, Pasteur's empire combina ferramentas analíticas próprias à história da ciência, à história da medicina e à história global a fim de mapear as consequências políticas e científicas do encontro entre a microbiologia e o império francês. Cronologicamente, o livro abarca uma faixa de tempo compreendida entre o início da colonização francesa na Indochina, na última década do século XIX, até a capitulação de 1940, que encerra oficialmente a Terceira República. Geograficamente, embora tenha uma pretensão quase totalizante expressa em seu título, o livro recobre sobretudo a França e as colônias da Indochina (atuais Vietnã, Laos e Camboja), da Tunísia e do Senegal (este último parte integrante da então África Ocidental Francesa).

Aro Velmet trabalha um tema em particular em cada capítulo, indo desde a gestão de doenças epidêmicas como a peste bubônica, a febre amarela e a tuberculose em alguns desses espaços coloniais, passando pela tentativa dos pasteurianos em estabelecer um monopólio sobre a produção e venda de álcool na Indochina ou pela transformação geral dos pasteurianos, "monges ascetas" na metrópole, em grandes capitalistas coloniais. Após essa viagem por pelos menos três continentes ao longo de quase 50 anos, Velmet conclui que essa época pasteuriana na história da medicina possui características muito próximas da era atual: trabalho em rede, conectado ao mercado global e capaz de fornecer soluções orientadas para as causas biológicas e não sociais dos problemas. Em razão dessa similaridade, Velmet afirma que o deslocamento da microbiologia da França para as suas colônias desvela uma possível origem da saúde global.

De maneira geral, o livro de Velmet dialoga com duas principais correntes historiográficas. De um lado, ele se dirige às discussões sobre as relações complexas entre medicina, ciência e impérios em contextos de língua inglesa. Velmet lembra portanto que a dominação do mundo não foi apanágio britânico nem estado-unidense, e que os franceses também 
tiveram um império. Ele dialoga por outro lado com a historiografia francesa dedicada à microbiologia, sobretudo com a obra de Bruno Latour. De fato, o leitor encontrará ao longo dos capítulos o típico vocabulário do pensador francês - redes, centros de cálculo, atores não humanos -, o que faz o livro de Velmet parecer em alguns momentos uma sequência de The Pasteurization of France, em que, dessa vez, o império contra-ataca.

Para além de ser um livro agradável e bem construído, a principal força de Pasteur's empire reside em que ele complementa e complexifica The Pasteurization of France. Como aponta Latour (2001, p.222-234) ao fim da parte empírica do seu livro, para se compreender a capacidade transformativa da microbiologia após a criação do soro antidiftérico, em 1894, a atenção deve se voltar, ao menos até 1914, para as colônias francesas, pois é ali que os pasteurianos, como "Solons dos trópicos", legislam e transformam tais sociedades. A afirmação de Latour se baseia porém em pouca, ou quase nenhuma, pesquisa documental, o que Velmet por outro lado faz muito bem. Partindo de diferentes arquivos situados na França e em suas antigas possessões, ele mapeia não apenas como os pasteurianos mudaram e moldaram o império francês para muito além de 1914, mas como o império os transformou nesse meio-tempo. Velmet mostra também como as estruturas de poder, um tópico sempre problemático em análises que utilizam o ferramental latouriano, revelam-se presentes ao longo da saga pasteuriana nos trópicos; se os cientistas conseguem transformar as sociedades coloniais, essa transformação é limitada e deve ser negociada a quase todo momento com a administração colonial e em menor escala com os próprios "colonizados".

Apesar desse interesse, a leitura do livro de Velmet desperta também três principais inquietações, a começar pela ideia de que o império mudou a microbiologia, a ela atribuindo uma dimensão capitalista. Na verdade, o Instituto Pasteur foi sempre pensado e agiu como uma empresa capitalista, e os estudos sobre a tentativa de Pasteur em controlar monopolisticamente o comércio da vacina anticarbunculosa, um pouco antes do período analisado no livro, ilustram muito bem essa situação (Cassier, 2008). A ida aos trópicos com certeza alterou algumas práticas da microbiologia e os próprios microbiologistas, mas o império não transformou totalmente a microbiologia, posto que na França ela não era mais "pura" e menos conectada aos interesses capitalistas do que nas colônias.

Embora o livro de Velmet seja um estudo centrado sobre o império francês, ele pretendia também cobrir o "mundo". Esse mundo não é visto, no entanto, só pelas lentes francesas. Assim, em segundo lugar, ao se concentrar quase exclusivamente sobre os pasteurianos franceses ao longo de debates que ultrapassavam em muitos aspectos as fronteiras daquele império, como a crise provocada pela pandemia de peste bubônica no final do século XIX ou as tentativas de se encontrar uma vacina para a febre amarela nos anos 1920, Velmet dá a falsa impressão de que seus atores possuíam uma capacidade de ação global inigualável. O leitor sentirá falta precisamente de outras vozes capazes de enriquecer a análise das redes pasteurianas, vozes brasileiras por exemplo, tão presentes nos debates internacionais sobre a peste bubônica quanto naqueles sobre a febre amarela.

Em terceiro lugar, ao afirmar que a saúde global possui uma origem pasteuriana, Velmet faz uma análise teleológica. De fato, o conceito de saúde global vem funcionando muitas vezes como um imã, atraindo para si a maioria dos estudos em história da medicina e da 
saúde. Em vez dessa quase obsessão com as origens ou com a antecipação da saúde global já no início do século XX, seria talvez mais proveitoso pensar em termos de histórias globais da saúde. Tais histórias poderiam ser capazes de mostrar como os saberes e as práticas da medicina foram construídos, validados, reconfigurados e contestados em um momento de densificação das interações humanas como a era dos impérios; um período de tempo no qual os europeus exercem um grande poder, mas não o exercem sozinhos. A análise de Velmet dá assim indícios importantes tanto de como contar uma história global da saúde quanto das dificuldades que existem para realizá-la.

\section{REFERÊNCIAS}

CASSIER, Maurice.

Producing, controlling, and stabilizing Pasteur's anthrax vaccine: creating a new industry and a health market. Science in Context, v.21, n.2, p.253-278. 2008.
LATOUR, Bruno.

Pasteur: guerre et paix des microbes. Paris: La Découverte. 2001.

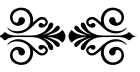

